\title{
LITHOLOGY, THICKNESS, AND EXTENT OF HYDROGEOLOGIC UNITS UNDERLYING THE EAST PORTLAND AREA, OREGON
}

By Susan V. Hartford and William D. McFarland

U.S. GEOLOGICAL SURVEY

Water-Resources Investigations Report 88-4110

Prepared in cooperation with the

CITY OF PORTLAND 


\author{
DEPARTMENT OF THE INTERIOR \\ MANUEL LUJAN, JR., Secretary \\ U.S. GEOLOGICAL SURVEY \\ Dallas L. Peck, Director
}

For additional information

write to:

Oregon Office Chief

U.S. Geological Survey

10615 S.E. Cherry Blossom Drive

Portland, Oregon 97216
Copies of this report can be purchased from:

U.S. Geological Survey Books and Open-File Reports Section Box 25425

Federal Center, Building 810

Denver, Colorado 80225 


\section{CONTENTS}

Page

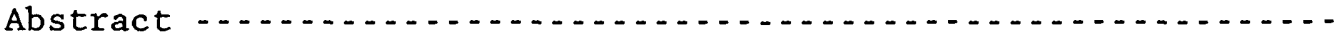

Introduction

Purpose and scope

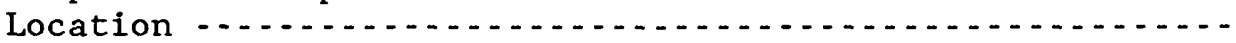

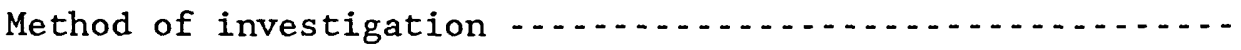

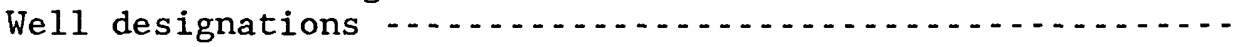

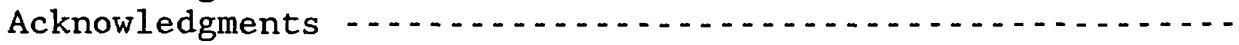

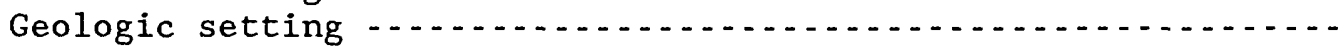

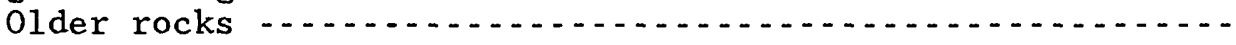

Sandy River Mudstone and Troutdale Formation ...........

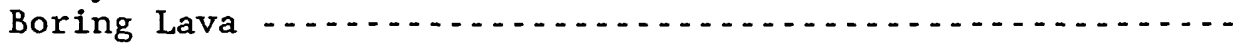

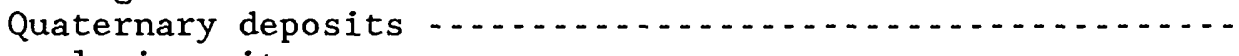

Hydrogeologic units $\ldots . .12$

Sand and gravel aquifer

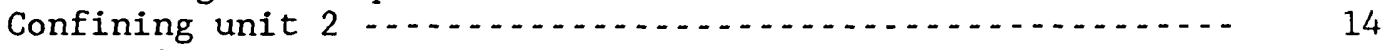

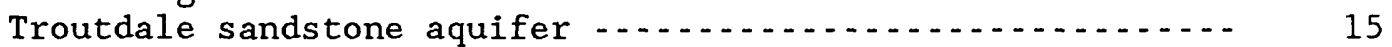

Confining unit 1 ...

Unconsolidated gravel/Troutdale gravel aquifer ........ 17

Blue Lake gravel aquifer ............................... 18

Columbia River sand aquifer .............................. 18

Overbank deposits

Summary -......

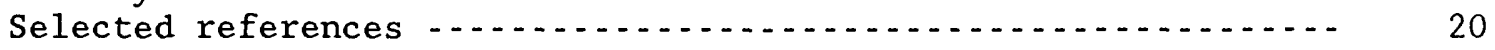




\section{MAP SHEETS}

1. Geologic map and cross-section of hydrogeologic units of the East Portland area, Oregon, showing locations or representative wells and borings.

2. Maps showing altitude of the top of the sand and gravel aquifer and altitude of the top and thickness of confining unit 2 .

3. Maps showing altitude of the top and thickness of the Troutdale sandstone aquifer.

4. Maps showing altitude of the top and thickness of confining unit 1 .

5. Maps showing altitude of the top and thickness of the unconsolidated gravel/Troutdale grave1 aquifer.

6. Maps of the Columbia River sand aquifer and the Blue Lake gravel aquifer showing thickness and altitude of the top and bottom; and a map showing the thickness of the overbank deposits.

\section{ILLUSTRATIONS}

Page

Figure 1. Map showing location of study area

2. Diagram showing well-numbering system -......... 8

3. Generalized stratigraphic correlation chart of regional area

4. Map showing facies distribution of the Troutdale

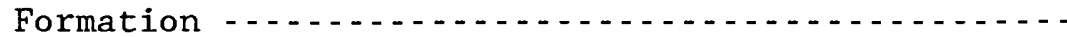

5. Chart showing correlation of informal hydrogeologicunit names used in this study with those used by previous investigators

TABLES

Table 1. Records of representative wells and borings in

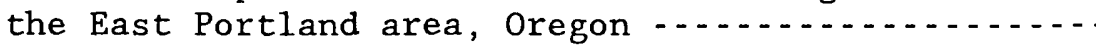


For the convenience of readers who may prefer to use metric (International System) units rather than the inch-pound units used in this report, values may be converted by using the following factors:

Multiply inch-pound unit

\begin{tabular}{|c|c|c|}
\hline \multicolumn{3}{|c|}{ Length } \\
\hline $\begin{array}{l}\text { foot (ft) } \\
\text { mile (mi) }\end{array}$ & $\begin{array}{l}0.3048 \\
1.609\end{array}$ & $\begin{array}{l}\text { meter }(\mathrm{m}) \\
\text { kilometer }(\mathrm{km})\end{array}$ \\
\hline \multicolumn{3}{|c|}{ Area } \\
\hline $\begin{array}{l}\text { square foot }\left(\mathrm{ft}^{2}\right) \\
\text { square mile }\left(\mathrm{mi}^{2}\right) \\
\text { acre } \\
\text { acre }\end{array}$ & $\begin{array}{c}0.09294 \\
2.590 \\
4,047 \\
0.4047\end{array}$ & $\begin{array}{l}\text { square meter }\left(\mathrm{m}^{2}\right) \\
\text { square kilometer }\left(\mathrm{km}^{2}\right) \\
\text { square meter }\left(\mathrm{m}^{2}\right) \\
\text { hectare }\end{array}$ \\
\hline \multicolumn{3}{|c|}{ Volume } \\
\hline $\begin{array}{l}\text { cubic foot }\left(\mathrm{ft}^{3}\right) \\
\text { gallon (gal) } \\
\text { gallon (gal) }\end{array}$ & $\begin{array}{l}0.02832 \\
0.003785 \\
3.785\end{array}$ & $\begin{array}{l}\text { cubic meter }\left(\mathrm{m}^{3}\right) \\
\text { cubic meter }\left(\mathrm{m}^{3}\right) \\
\text { liter }(\mathrm{L})\end{array}$ \\
\hline \multicolumn{3}{|c|}{$\underline{\text { Flow }}$} \\
\hline cubic foot per second $\left(\mathrm{ft}^{3} / \mathrm{s}\right)$ & 0.02832 & cubic meter per second $\left(\mathrm{m}^{3} / \mathrm{s}\right)$ \\
\hline
\end{tabular}

Sea level: In this report "sea level" refers to the National Geodetic Vertical Datum of 1929 (NGVD of 1929)--a geodetic datum derived from a general adjustment of the first-order level nets of both the United States and Canada, formerly called "Sea Level Datum of 1929." 


\section{LITHOLOGY, THICKNESS, AND EXTENT OF HYDROGEOLOGIC UNITS UNDERLYING THE EAST PORTLAND AREA, OREGON}

By Susan V. Hartford and William D. McFarland

\section{ABSTRACT}

The lithology, thickness, and extent of eight distinct hydrogeologic units are described and mapped within the study area. These units underlie the East Portland area of northwestern Oregon. The thickness, extent, and top of each unit are shown on contour maps at scales of 1:24,000. Their stratigraphic relations are displayed on a diagrammatic cross section. The geologic setting and unit lithology are described in the text. A data table presents information on each well or boring that was used for determining the thickness, extent, and lithology of each hydrogeologic unit.

The hydrogeologic units range in age from late Miocene to Holocene and include several facies of the Troutdale Formation and Sandy River Mudstone, as well as Quaternary deposits of the Columbia River. From oldest to youngest, these units are referred to as: the sand and gravel aquifer, confining unit 2, Troutdale sandstone aquifer, confining unit 1, unconsolidated gravel/Troutdale gravel aquifer, Columbia River sand aquifer, Blue Lake gravel aquifer, and overbank deposits. The total thickness of these sedimentary deposits is more than 1,300 feet in the study area.

\section{INTRODUCTION}

In 1975, the City of Portland Water Bureau (PWB) began a program to study the development of ground water as an alternative to surface water from the Bull Run watershed (Willis, 1977). After drilling and testing several exploratory wells, PWB proposed development of a well field along the south shore of the Columbia River in eastern Multnomah County (fig. 1 ). A final design capacity of 100 million gallons per day is projected for the completed well field. In 1987, 19 production wells had been completed, as well as more than 50 test, piezometer, and exploratory wells.

The PWB drilling program generated new geologic and hydrologic data that made possible the description of eight distinct hydrogeologic units within sediments of the Portland Basin. The U.S. Geological Survey, in cooperation with the City of Portland Water Bureau, began a study to map these eight units.

\section{Purpose and Scope}

The purpose of this report is to describe the lithology, thickness, and extent of a portion of the hydrogeologic system underlying the East Portland area. Knowledge of the hydrogeologic characteristics of the system and their relation to the regional geologic setting will strengthen the understanding of how ground water flows through the system. Mapping of the thickness and extent of the aquifers will provide input for a ground-water flow model of the Portland Basin. 


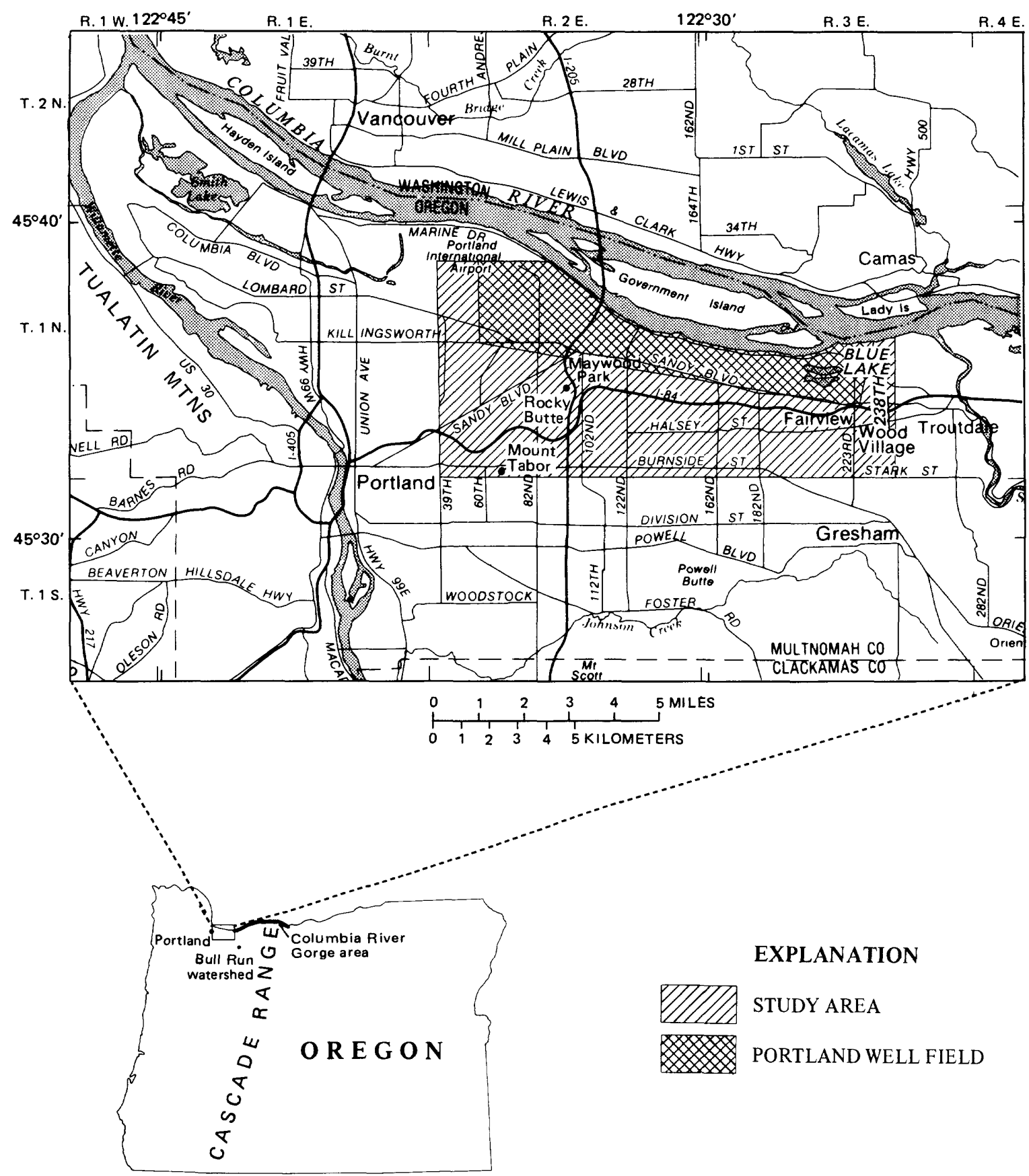

Figure 1,--Location of study area

\section{Location}

The study area includes approximately 35 square miles of eastern Multnomah County in northwestern Oregon. The contour maps center around the Portland well field area on the south shore of the Columbia River. The Columbia River forms the northern boundary of the study area. On the east, south and west, the study area is roughly bounded by N.E. 238th Avenue, S.E. Stark Street (Willamette Baseline), and N.E. 39th Avenue (fig. 1). The study boundary encloses all wells drilled by the PWB as of 1987 . 


\section{Method of Investigation}

Interpretation of geologic logs, natural gamma logs, aquifer test data, and selected driller reports was made to determine the altitude of the top of each unit and its thickness. These data are available in the Portland office of the U.S. Geological Survey.

Wells drilled for the PWB and some other well owners in the study area have been field located by the U.S. Geological Survey. Wells that have not been field located are located to the nearest 40-acre quarter-quarter section as reported in drillers reports, maps, surveys provided by the well owner, or in maps published in previous reports (Foxworthy and others, 1964; Hogenson and Foxworthy, 1965; Willis, 1977 and 1978). Wells used in this study are plotted on a base map at 1:24,000 (sheet 1) and are also referenced in table 1. The altitude of land surface at the well head has either been surveyed or estimated from topographic maps (contour interval, 10 feet).

\section{We11 Designations}

Designations of wells mentioned in this report are based on the official system for rectangular subdivision of public lands, referenced to the Willamette Base Line and Meridian. The well number indicates the location of the well by township, range, section, and the position of the well within the section (fig. 2). The first numeral indicates the township; the second, the range; the third, the section in which the well is located. The letters following the section number locate the well within the section. The first letter denotes the quarter section (160 acres); the second, the quarterquarter section ( 40 acres); the third, the quarter-quarter-quarter section (10 acres); and the fourth, the quarter-quarter-quarter-quarter section (2.5 acres). A number following the letters indicates one or more wells in the same subdivision. For example, well number $1 \mathrm{~N} / 2 \mathrm{E}-29 \mathrm{DABD} 1$ is in the SE 1/4, NW 1/4, NE 1/4, SE 1/4, Sec. 29, T.1 N., R.2 E. and is one well drilled in this subdivision.

On the well-location map (sheet 1 ), the section number and a two- or four-letter section subdivision and sequence number are shown adjacent to the well symbol. The township and range grid on sheet 1 follows surveyed township, range, and section lines where possible with a solid line; the line is dashed where inferred.

\section{Acknowledgments}

The authors acknowledge the contributions of several workers who recorded the formational material recovered during PWB drilling activities during the period 1976 to 1985. These workers include F. J. Frank, Constance Taylor, and David Cole, private consultants for the City of Portland Water Bureau; William Hoffstetter and Diane Partch with the City of Portland Water Bureau; and John Cooper and Kevin Foster with Geotechnical Resources Incorporated. The authors also thank the Oregon Water Resources Department (OWRD) for allowing Susan Hartford time from her duties at OWRD to make necessary revisions to the manuscript of this report during the review process.

\section{GEOLOGIC SETTING}

The extent and boundaries of the hydrogeologic system in the East Portland area are best understood by describing its relation to the regional geologic setting. Correlation of hydrogeologic units in the East Portland area with geologic units outside the study area is possible using lithologic, geochemical, and stratigraphic comparisons. 
WELL NUMBER: See text for description of well numbering system.

ALIITUDE: Altitude of land surface at well site is in reference to sea level. Surveyed where accuracy is shown in tahle; otherwise interpolated from topographic maps (contour intervel, 10 feet).

DEPTH OF WELL OR TUBE: Total depth drilled.

DIAMETER OF WELL OR TUBE: Diameter of outermost casing visible at. land surface (diameter of boring is that diameter visible at land surface)

DEPTH OF CASING: Depth of deepest Casing in the woll.

FINISH: $\quad P=$ perforated, $S=$ screened, $X=$ open hole, $O=$ open end, $A=$ abandoned, $B=$ backfilled. Interval shown is the open interval (except for

作 $O B=$ Overbank deposits, CRSA = Columbia River sand aquifer, BLGA = Blue Lake gravel aquifer, UG/TGA = unconsolidated gravel/Troutdale
gravel aquifer, CU1 = Confining unit 1 , ISA = Troutdale sandstone aquifer, CJ2 = Confining unit 2 , SGA = sand and gravel aquifer. For Bravel aquifer, CU1 = Confining

WATER LEVEL: Those water levels that are above land surface are preceded by a minus $(-)$ sign. Water levels are measured where accuracy is shown in tahle; otherwise, water levels are reported.

TYPE OF TEST: $\mathrm{P}=$ pump test; $B=$ bailer test; $A=$ air test; $R=$ reported.

REMARKS: Owner's well number noted where known.

DATA AVAILABILITY: Dashed ("--") where data 15 unavailable; queried ("??") where interpretation of data is uncertain or unknown; " " 1ndicates

ABBREVIATIONS used: $\mathrm{TW}=$ test well; $\mathrm{PW}=$ production well; $\mathbf{W W}=$ northwest; $\mathrm{N} / \mathrm{A}=$ not applicable; $\mathrm{ABD}=$ abandoned; $\mathrm{RPT}=\mathrm{reported} ; \mathrm{OR}=\mathrm{Oregon} ; \mathrm{BPm}=\mathrm{Ballons}$

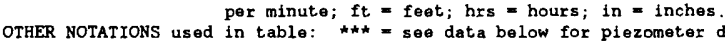

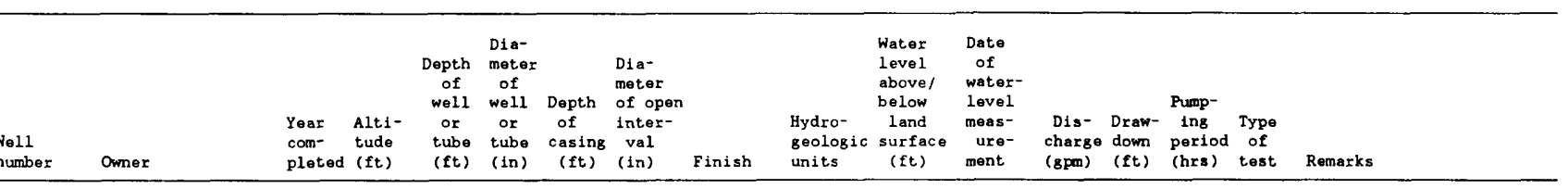

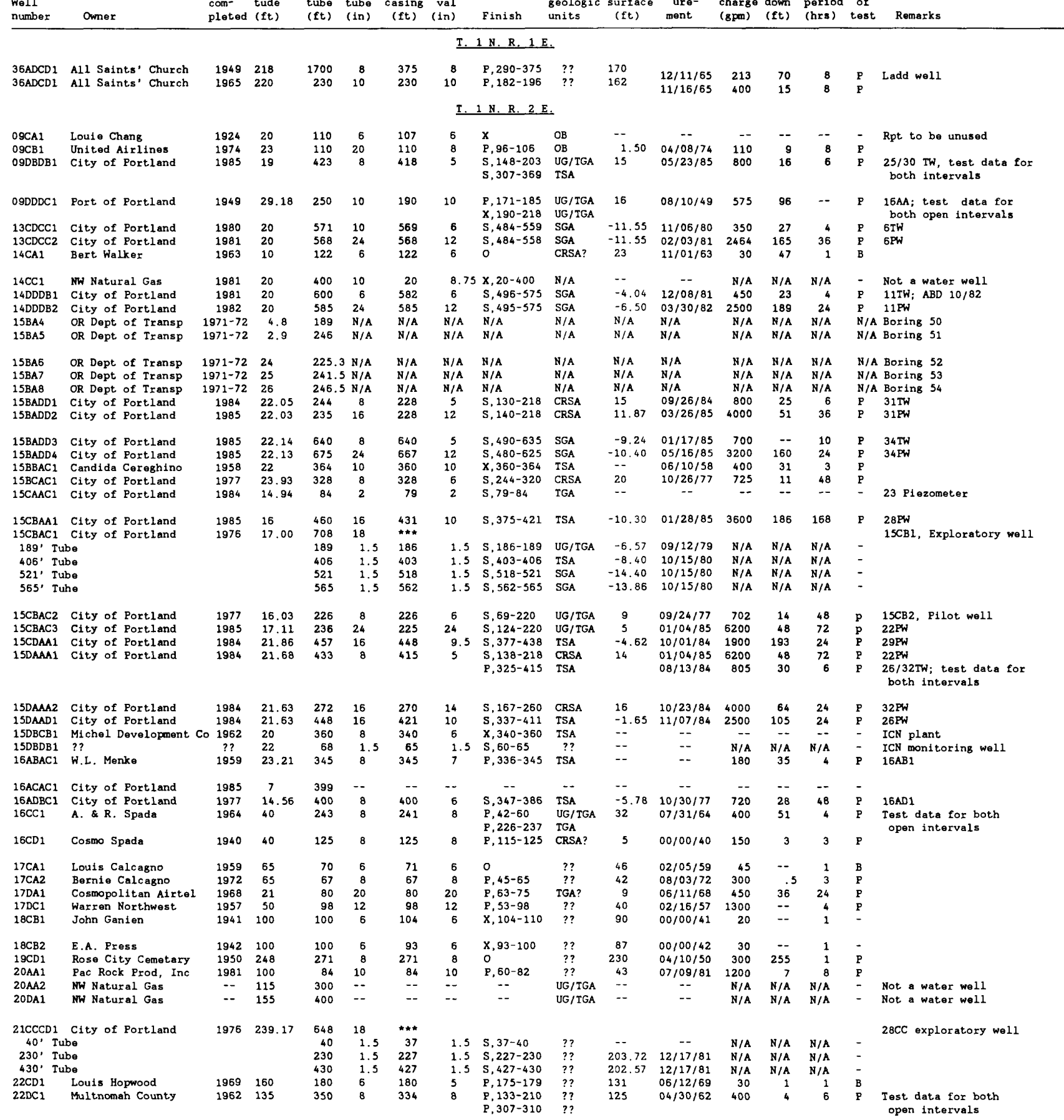




\begin{tabular}{|c|c|c|c|c|c|c|c|c|c|c|c|c|c|c|c|c|}
\hline $\begin{array}{l}\text { We11 } \\
\text { number }\end{array}$ & Owner & $\begin{array}{l}\text { Year } \\
\text { com- } \\
\text { pleted }\end{array}$ & $\begin{array}{l}\text { Alti- } \\
\text { tude } \\
\text { (ft) }\end{array}$ & $\begin{array}{c}\text { Depth } \\
\text { of } \\
\text { wel1 } \\
\text { or } \\
\text { tube } \\
\text { (ft) }\end{array}$ & $\begin{array}{l}\text { Dia- } \\
\text { meter } \\
\text { of } \\
\text { well } \\
\text { or } \\
\text { tube } \\
\text { (1n) }\end{array}$ & $\begin{array}{l}\text { Depth } \\
\text { of } \\
\text { casing } \\
\text { (ft) }\end{array}$ & $\begin{array}{l}\text { Dia- } \\
\text { meter } \\
\text { of open } \\
\text { inter- } \\
\text { val } \\
\text { (in) }\end{array}$ & Finish & $\begin{array}{l}\text { Hydro- } \\
\text { geologic } \\
\text { units }\end{array}$ & $\begin{array}{l}\text { Water } \\
\text { level } \\
\text { above/ } \\
\text { below } \\
\text { land } \\
\text { surface } \\
\text { (ft) }\end{array}$ & $\begin{array}{l}\text { Date } \\
\text { of } \\
\text { water- } \\
\text { leve1 } \\
\text { meas- } \\
\text { ure- } \\
\text { ment }\end{array}$ & $\begin{array}{l}\text { Dis- } \\
\text { charge } \\
\text { (gpa) }\end{array}$ & $\begin{array}{l}\text { Draw- } \\
\text { down } \\
(f t)\end{array}$ & $\begin{array}{l}\text { Pump- } \\
\text { Ing } \\
\text { poriod } \\
\text { (hrs) }\end{array}$ & $\begin{array}{c}\text { Type } \\
\text { of } \\
\text { test }\end{array}$ & Remarks \\
\hline & & & & & & & T. 1 & $1 \mathrm{~N}, \mathrm{R}, 2 \mathrm{E}$ & & & & & & & & \\
\hline 23AACB 1 & Joe GrosJaques & 1967 & 20 & 365 & 10 & 215 & 8-10 & $P, 112-215$ & $\underset{\text { UG } / \text { TGA / }}{\text { CU1 }}$ & 12.50 & $02 / 04 / 67$ & 80 & 40 & 30 & $\mathrm{P}$ & $\begin{array}{l}\text { Test data for both } \\
\text { open intervals }\end{array}$ \\
\hline 23BCAC1 & Parkrose Water Dist & 1970 & 30 & 65 & 34 & 65 & 24 & $\begin{array}{l}\text { B, 215-365 } \\
S, 41-61\end{array}$ & $\begin{array}{l}\text { N/A } \\
\text { UG/TGA }\end{array}$ & 17 & $02 / 18 / 70$ & 2325 & 25 & 26 & $p$ & 3PW \\
\hline $23 \mathrm{BCDB} 1$ & Parkrose Water Dist & 1965 & 31 & 63 & 24 & 63 & 24 & s, 33-63 & UG/TGA & 24 & $01 / 22 / 62$ & $\begin{array}{l}2323 \\
2450\end{array}$ & $\begin{array}{l}25 \\
13\end{array}$ & $\begin{array}{l}26 \\
16\end{array}$ & P & $2 \mathrm{PW}$ \\
\hline 23DAI & Pierce Trainer \& Eqp & 1959 & 45 & 63 & 6 & -- & -- & - & UG/TGA & -- & -- & 40 & 10 & - & B & \\
\hline 23DB 1 & George Okita & 1955 & 40 & 47 & 6 & 47 & 6 & 0 & UG/TGA & 19 & $11 / 02 / 55$ & 35 & 10 & -- & $\mathbf{B}$ & \\
\hline 24AA1 & Amil Spada & 1980 & 10 & 87 & 6 & 83 & 6 & $5,82-87$ & UG/TGA & 11.50 & $12 / 16 / 80$ & 85 & 2 & 2 & $\mathbf{P}$ & \\
\hline $24 \mathrm{AABC1}$ & City of Portland & 1979 & 25.35 & 520 & -- & -- & -- & A & N/A & 20 & $10 / 29 / 79$ & -. & $\therefore$ & - & - & $1 \mathrm{TW}$ \\
\hline $24 \mathrm{AABC} 2$ & City of Portland & 1980 & 25.35 & 531 & 20 & 520 & 10 & $S, 389-515$ & SGA & -11.55 & $07 / 11 / 80$ & 2400 & 80 & 3 & $\mathbf{P}$ & $1 \mathrm{PW}$ \\
\hline 24AACC 1 & City of Portland & 1977 & 25.13 & 490 & 8 & 490 & 6 & $5,425-489$ & $\mathrm{SGA}$ & -6.93 & $11 / 14 / 77$ & 647 & 37 & 48 & $P$ & $24 \mathrm{AA2}$ \\
\hline $24 \mathrm{ACl}$ & KKSN Radio & 1985* & 20 & 51 & 6 & 51 & 4 & $P, 37-50$ & UG/TGA & 5 & $05 / 29 / 85$ & 50 & 17 & 1 & A & \\
\hline $24 A D 1$ & B.A. Wagner & 1960 & 15 & 60 & 6 & 61 & 6 & & $\mathrm{UG} / \mathrm{TGA}$ & 6 & $08 / 02 / 60$ & 40 & 30 & 1 & B & \\
\hline $24 \mathrm{AD2}$ & Harry Venema & 1971 & 20 & 76 & 6 & 77 & 5 & $P, 70-76$ & UG/TGA & 13 & $10 / 09 / 71$ & -- & -- & -- & - & \\
\hline 24ADCB 1 & City of Portland & 1977 & 17 & 330 & 8 & 320 & 6 & S, $251-320$ & TSA & -10.16 & $12 / 16 / 77$ & 730 & 50 & 48 & $\mathbf{P}$ & $24 \mathrm{AD} 2$ \\
\hline $24 \mathrm{ADCB} 2$ & City of Portland & 1980 & 17 & 538 & 24 & 509 & 12 & $5,411-504$ & $S G A$ & -10.40 & $06 / 21 / 82$ & 3000 & 129 & 24 & $P$ & $2 \mathrm{PW}$ \\
\hline $24 \mathrm{ADCC} 1$ & City of Portland & 1977 & 13.93 & 505 & 8 & 500 & 6 & $S, 380-489$ & SGA & -13.86 & $08 / 16 / 77$ & 700 & 14 & 36 & $\mathbf{P}$ & $2 \mathrm{TW}$ \\
\hline $24 \mathrm{BA} 1$ & Roy K. Roberts & 1964 & 20 & 50 & 6 & 51 & 6 & 0 & UG/TGA & 9 & $10 / 07 / 64$ & 100 & 1 & 10 & $P$ & \\
\hline $24 \mathrm{BA} 2$ & Roy X. Roberts & 1976 & 20 & 104 & 6 & 104 & 6 & 0 & UG/TGA & 9.50 & $09 / 01 / 76$ & 24 & 76 & 4 & B & \\
\hline $24 \mathrm{BA3}$ & Tuhe Specialities, Inc & $=1985$ & 20 & 280 & 6 & 268 & 5 & $S, 268-278$ & TSA & 28 & $07 / 25 / 85$ & 68 & 76 & 4 & $\mathbf{P}$ & \\
\hline 24BDBD 1 & City of Portland & 1981 & 15 & 395 & 6 & 389 & 6 & $5,283-365$ & TSA & -3.47 & $09 / 11 / 81$ & 450 & 27 & 4 & $\mathrm{P}$ & $10 T w$ \\
\hline 24BDBD2 & City of Portland & 1982 & 15 & 375 & 16 & 375 & 12 & S, 282-365 & TSA & -3.47 & $01 / 12 / 82$ & 2500 & 196 & 48 & $\mathbf{P}$ & 10PW \\
\hline $24 \mathrm{CA} 1$ & Shady Rest Auto Park & 1941 & 45 & 54 & 6 & 54 & 6 & 0 & UG/TGA & -- & -- & 30 & -- & -- & - & \\
\hline $24 \mathrm{CA2}$ & Pacific Equipment Co & 1965 & 20 & 35 & 6 & 35 & 6 & 0 & UG/TGA & 2.50 & $07 / 16 / 65$ & 75 & 3 & 2 & $\mathbf{P}$ & \\
\hline $24 \mathrm{CA3}$ & J.W. Huserick & 1965 & 28 & 27 & 6 & 24 & 6 & $x, 24-27$ & UG/TGA & 5 & $08 / 22 / 65$ & 15 & 2 & 2 & B & \\
\hline $24 \mathrm{CA}_{4}$ & David \& Adele Nelsen & 1976 & 25 & 58 & 6 & 58 & 6 & 0 & UG/TGA & 43 & $07 / 06 / 76$ & 20 & 2 & 4 & B & \\
\hline $24 \mathrm{CACA} 1$ & City of Portland & 1983 & 39 & 568 & 6 & 562 & 6 & $S, 442-552$ & SGA & 3 & $05 / 13 / 83$ & 425 & 45 & 4 & $P$ & $16 \mathrm{TW}$ \\
\hline $24 \mathrm{CACA2}$ & City of Portland & 1983 & 39 & 560 & 22 & 560 & 12 & $5,419-550$ & SGA & 3.90 & $07 / 27 / 83$ & 2500 & 127 & 24 & $\mathbf{P}$ & $16 \mathrm{PW}$ \\
\hline $24 \mathrm{CD} 1$ & John W. Wolf & 1949 & 45 & 86 & 6 & 86 & 6 & 0 & UG/TGA & 60 & $09 / 00 / 49$ & 10 & 10 & 1 & - & \\
\hline $24 \mathrm{CD2}$ & Ira Wills & 1957 & 45 & 63 & 6 & 62 & 6 & $x, 62-63$ & $\mathrm{UG} / \mathrm{TGA}$ & 33 & $07 / 22 / 57$ & 40 & -- & 1 & B & \\
\hline 24 CDAC1 & Steve Caleagno & 1971 & 70 & 90 & 8 & 90 & 8 & P, 70-85 & $\mathrm{UG} / \mathrm{TGA}$ & 53 & $02 / 08 / 71$ & 215 & 1 & $\begin{array}{l}1 \\
8\end{array}$ & $P$ & \\
\hline $24 \mathrm{DA} 1$ & Eddie \& Mary Wegner & 1962 & 20 & 107 & 6 & 107 & 6 & 0 & UG/TGA & 10 & $08 / 08 / 62$ & 60 & 50 & 4 & B & \\
\hline 24DABB1 & City of Portland & 1976 & 18.40 & 548 & 18 & $\star \star \star \star$ & & & & & & & & & & 24DA1, exploratory well \\
\hline $80 . \mathrm{Tu}$ & & & 17.65 & 80 & 1.5 & 77 & 1.5 & $5,77-80$ & $\mathrm{UG} / \mathrm{TGA}$ & -6.37 & $11 / 09 / 81$ & $\mathrm{~N} / \mathrm{A}$ & N/A & $\mathrm{N} / \mathrm{A}$ & - & \\
\hline $270^{\circ} \mathrm{Tu}$ & & & 17.96 & 270 & 1.5 & 267 & 1.5 & $S, 267-270$ & TSA & -1.03 & $11 / 09 / 81$ & $\mathbf{N} / \mathbf{A}$ & $\mathrm{N} / \mathrm{A}$ & N/A & - & \\
\hline $315^{\prime} \mathrm{Tu}$ & & & 17.94 & 315 & 1.5 & 312 & 1.5 & S, 312-315 & TSA & 0.94 & $11 / 09 / 81$ & $\mathrm{~N} / \mathrm{A}$ & $\mathrm{N} / \mathrm{A}$ & $\mathrm{N} / \mathrm{A}$ & - & \\
\hline $390, \mathrm{Tu}$ & & & 17.56 & 390 & 1.5 & 387 & 1.5 & $5,387-390$ & SGA & 9.93 & $11 / 09 / 81$ & $\mathrm{~N} / \mathrm{A}$ & $\mathrm{N} / \mathrm{A}$ & $\mathrm{N} / \mathrm{A}$ & - & \\
\hline $430^{\prime} \mathrm{Tu}$ & & & 17.60 & 430 & 1.5 & 427 & 1.5 & $5,427-430$ & SGA & 9.87 & $11 / 09 / 81$ & $\mathrm{~N} / \mathrm{A}$ & N/A & N/A & - & \\
\hline $490^{\prime} \mathrm{Tu}$ & ibe & & 18.10 & 490 & 1.5 & 487 & 1.5 & $S, 487-490$ & SGA & 9.82 & $11 / 09 / 81$ & $\mathrm{~N} / \mathrm{A}$ & $\mathrm{N} / \mathrm{A}$ & $\mathrm{N} / \mathrm{A}$ & - & \\
\hline 24001 & Parkrose Water Dist & 1981 & 39 & 680 & -- & -- & -- & A & $\mathrm{N} / \mathrm{A}$ & -. & -- & N/A & N/A & $\mathrm{N} / \mathrm{A}$ & - & \\
\hline $25 A D 1$ & City of Portland & 1981 & 150 & 500 & 10 & 29 & -- & $x, 29-500$ & $\begin{array}{l}\text { UG/TGA/ } \\
\text { TSA }\end{array}$ & -- & -- & H/ & $\begin{array}{ll}n / n \\
--\end{array}$ & -- & - & \\
\hline 25BA1 & Blair Holcomb & 1947 & 95 & 133 & 8 & -- & - & $P, 47-88$ & UG/TGA & 92.6 & $05 / 00 / 49$ & -- & -- & -- & - & \\
\hline $25 \mathrm{BA} 2$ & C.P. Springsted & 1949 & 100 & 75 & 6 & 74 & 6 & $x, 74-75$ & $\mathrm{UG} / \mathrm{TGA}$ & 52 & $00 / 00 / 49$ & 32 & -- & 2 & - & \\
\hline $25 \mathrm{BA} 3$ & Ronald Young & 1962 & 98 & 70 & 6 & 66 & 6 & $x, 66-70$ & UG/TGA & so & $01 / 08 / 62$ & 30 & -- & -- & - & \\
\hline $25 \mathrm{CBCC} 1$ & Richland Water Dist & 1956 & 252 & 490 & 12 & 335 & 12 & $P, 145-330$ & UG/TGA & 145 & $09 / 12 / 56$ & 220 & 94 & 4 & $\mathbf{P}$ & No. 2 \\
\hline $25 \mathrm{CC} 1$ & Pete Place & - & 260 & 142 & 6 & - & -- & - & UG/TGA & 126.81 & $04 / 26 / 57$ & - & - & $\therefore$ & - & \\
\hline $26 \mathrm{CB} 1$ & Parkrose School Dist & 1958 & 279 & 415 & 10 & 400 & 10 & $\begin{array}{l}P, 222-226 \\
P, 374-386\end{array}$ & $\begin{array}{l}\text { UG/TGA } \\
\text { UG/TGA? }\end{array}$ & 236 & $07 / 23 / 58$ & 450 & 9 & 5 & $\mathbf{P}$ & $\begin{array}{l}\text { Test data for both } \\
\text { open intervals }\end{array}$ \\
\hline $26 \mathrm{CB} 2$ & Columbia Sand \& Grv1 & 1961 & 280 & 388 & 8 & 377 & 6 & $P, 305-370$ & UG/TGA & 203 & $04 / 15 / 61$ & 140 & 23 & 24 & P & \\
\hline 26DD1 & Richland Water Dist & 1947 & 255 & 400 & 12 & 388 & 10 & P. $165-383$ & UG/TGA & 128 & $03 / 00 / 47$ & 240 & 50 & 12 & $\mathrm{P}$ & No. 1 \\
\hline 26002 & Richland Water Dist & 1959 & 260 & 470 & 12 & 445 & $8-12$ & $P, 315-440$ & $\mathrm{UG} / \mathrm{TGA}$ & 199 & $07 / 15 / 59$ & 325 & 88 & 6 & $\mathrm{P}$ & No. 3 \\
\hline 26003 & Richland Water Dist &.- & 260 & 300 & - & -- & -- & -. & -- & 150 & -. &.- & - & - & - & \\
\hline $26 D_{4} 4$ & Richland Water Dist & 1960 & 265 & 250 & 16 & 250 & 8 & $P, 195-250$ & UG/TGA & 140 & $05 / 21 / 60$ & 195 & 51 & 14 & $\mathrm{P}$ & so. 4 \\
\hline $27 \mathrm{BB1}$ & Parkrose Water co & 1952 & 210 & 265 & 12 & 265 & 12 & $P, 217-247$ & UG/TGA & 198 & $04 / 03 / 52$ & 750 & .63 & 8 & $\mathrm{P}$ & \\
\hline $27 \mathrm{DCCC} 1$ & City of Portland & 1976 & 291.90 & 835 & 18 & $\star \star \star \star$ & & & & & & & & & & 27DC1, Exploratory well \\
\hline $80^{\circ} \mathrm{Tu}$ & be & & 291.22 & 80 & 1.5 & 77 & 1.5 & $5,77-80$ & UG/TGA & -- & -- & $\mathrm{N} / \mathrm{A}$ & N/A & $\mathrm{N} / \mathrm{A}$ & - & \\
\hline $229 \cdot \mathrm{Tu}$ & & & 291.36 & 229 & 1.5 & 226 & 1.5 & $5,226-229$ & $\mathrm{UG} / \mathrm{TGA}$ & -- & -- & $\mathbf{N} / \mathbf{A}$ & $\mathrm{N} / \mathrm{A}$ & $\mathbf{N} / \mathbf{A}$ & - & \\
\hline $442^{\prime} \mathrm{Tu}$ & & & 291.48 & 439 & 1.5 & 429 & 1.5 & $5,439-442$ & UG/TGA & 249.38 & $10 / 28 / 81$ & $\mathrm{~N} / \mathrm{A}$ & $\mathrm{N} / \mathrm{A}$ & $\mathrm{N} / \mathrm{A}$ & - & \\
\hline 708' Tu & & & 291.23 & 708 & 1.5 & 705 & 1.5 & S, 705-708 & SGA & - & - & $\mathrm{N} / \mathrm{A}$ & $\mathrm{N} / \mathrm{A}$ & N/A & - & \\
\hline $780^{\prime} \mathrm{Tu}$ & & & 290.83 & 780 & 1.5 & 777 & 1.5 & $5,777-780$ & SGA & 254.53 & $10 / 28 / 81$ & $\mathrm{~N} / \mathrm{A}$ & $\mathrm{N} / \mathrm{A}$ & $\mathrm{N} / \mathrm{A}$ & - & \\
\hline $28 \mathrm{BCBC1}$ & Lavelle/Yett Landfill & 1973 & 170 & $\begin{array}{l}75 \\
41\end{array}$ & 12 & 36 & & $\begin{array}{l}\star \star \star \star \\
--\end{array}$ & $\begin{array}{l}N / A \\
U G / T G A\end{array}$ & 38.67 & $03 / 08 / 73$ & $\begin{array}{l}\text { N/A } \\
\text { N/A }\end{array}$ & $\begin{array}{l}\mathrm{N} / \mathrm{A} \\
\mathrm{N} / \mathrm{A}\end{array}$ & N/A & - & Piezometer well \\
\hline $\begin{array}{l}41, \mathrm{Tu} \\
72, \mathrm{Tu}\end{array}$ & & & & $\begin{array}{l}41 \\
72\end{array}$ & -- & -- & -- & -- & $\begin{array}{l}\text { UG/TGA } \\
\text { UG/TGA }\end{array}$ & -- & -- & $\begin{array}{l}\text { N/A } \\
\text { N/A }\end{array}$ & $\begin{array}{l}\text { N/A } \\
\text { N/A }\end{array}$ & $\begin{array}{l}\mathrm{N} / \mathrm{A} \\
\mathrm{N} / \mathrm{A}\end{array}$ & - & \\
\hline $28 B C C B 1$ & Rose City Sand \& Grvl & 1936 & 215 & 200 & 8 & 200 & 8 & $P, 165-195$ & $\begin{array}{l}\text { UG/TGA } \\
\text { UG/TGA }\end{array}$ & -. & -- & $\begin{array}{l}\text { N/A } \\
\sim 60\end{array}$ & N/A & N/A & - & \\
\hline 29DA1 & City of Portland & 1969 & 205 & 417 & 12 & 417 & $10-12$ & $P, 195-416$ & $\mathrm{UG} / \mathrm{TGA}$ & 160 & $03 / 11 / 69$ & 776 & 39 & 2 & $P$ & Rose City Golf Course \\
\hline 29DABD1 & City of Portland & 1976 & 204.43 & 1210 & 18 & $\star \star \star \star$ & & & & & & & & & & 29DA1, Exploratory we11 \\
\hline $204^{\prime} \mathrm{Tu}$ & be & & 203.52 & 204 & 1.5 & 201 & 1.5 & $5,201-204$ & UG/TGA & 152.05 & $05 / 16 / 84$ & N/A & $\mathrm{N} / \mathrm{A}$ & $\mathrm{N} / \mathrm{A}$ & - & \\
\hline $447^{\prime} \mathrm{Tu}$ & & & 203.53 & 447 & 1.5 & 444 & 1.5 & $5,444-447$ & UG/TGA & 159.65 & $05 / 16 / 84$ & $\mathbf{N} / \mathbf{A}$ & $\mathrm{N} / \mathrm{A}$ & $\mathrm{N} / \mathrm{A}$ & - & \\
\hline $713^{\prime} \mathrm{Tu}$ & & & 203.74 & 713 & 1.5 & 700 & 1.5 & $5,700-713$ & $\mathrm{SGA}$ & 161.73 & $05 / 16 / 84$ & $\mathrm{~N} / \mathrm{A}$ & $\mathbf{N} / \mathrm{A}$ & $\mathrm{N} / \mathrm{A}$ & - & \\
\hline 809' Tu & & & 203.51 & 809 & 1.5 & 806 & 1.5 & $5,806-809$ & SGA & 169.10 & $05 / 16 / 84$ & $\mathrm{~N} / \mathrm{A}$ & $\mathrm{N} / \mathrm{A}$ & $\mathrm{N} / \mathrm{A}$ & - & \\
\hline $29 \mathrm{CB} 1$ & City of Portland & 1968 & 185 & 265 & 12 & 263 & 12 & $P, 215-256$ & UG/TGA & 141 & $06 / 21 / 68$ & 990 & 50 & 6 & $P$ & \\
\hline $290 B 1$ & Rose City Golf Course & 1945 & 212 & 203 & 10 & 208 & 8 & $P, 160-203$ & UG/TGA & 140 & $09 / 00 / 45$ & 400 & - & $\therefore$ & - & \\
\hline $29 \mathrm{DC} 1$ & NW Natural Gas Co & 1983 & 222 & 298 & 10 & 250 & 1 & -- & N/A & -- & -- & $\mathrm{N} / \mathrm{A}$ & $\mathrm{N} / \mathrm{A}$ & $\mathrm{N} / \mathrm{A}$ & - & Not a water well \\
\hline $30 \mathrm{CCl}$ & R.W. Mangels & 1945 & 160 & 163 & 8 & -. & 8 & $P, 151-157$ & UG/TGA & 124 & $08 / 00 / 45$ & 50 & 14 & 1 & $\mathbf{P}$ & \\
\hline $31 \mathrm{CB} 1$ & Providence Hospital & 1947 & 200 & 164 & 12 & -- & $\ldots$ & $P, 136-148$ & UG/TGA & 116 & $02 / 22 / 62$ & 360 & 8 & 2 & $P$ & \\
\hline $31 \mathrm{CDI}$ & Williarn Reed & $\ldots$ & 195 & 170 & -- & -. & -- & - & -- & - & -. & -- & -- & - & - & \\
\hline $32 \mathrm{BD} 1$ & Fred Meyer & 1961 & 255 & 295 & 12 & 295 & 12 & $P, 185-280$ & UG/TGA & 150 & $09 / 15 / 61$ & 500 & 42 & 8 & $\mathbf{P}$ & \\
\hline 32DD1 & Montavílla Icescoal & $\sim 1919$ & 258 & 197 & 6 & .. & -- & -. & -. & -- & -- & -- & -- & - & - & \\
\hline 33DABA1 & Russellville Wtr Dist & 1941 & 287 & 252 & 12 & 252 & 12 & P. $243-248$ & UG/TGA & 228 & $04 / 00 / 41$ & 250 & 18 & -- & $\mathbf{P}$ & \\
\hline 33DAAB1 & Russellville Wtr Dist & 1941 & 287 & 304 & 12 & 304 & 12 & $P, 222-290$ & UG/TGA & 229 & $11 / 00 / 41$ & 300 & 22 & -- & $\mathbf{P}$ & \\
\hline $34 \mathrm{AB1}$ & Hazelwood Wtr Dist & 1977 & 290 & 500 & 12 & 500 & 8 & $5,415-490$ & UG/TGA & 260 & $11 / 21 / 77$ & 575 & 63 & 12 & $\mathbf{P}$ & \\
\hline $34 \mathrm{AB} 2$ & Hazelwood Wtr Dist & 1982 & 289 & 500 & 12 & 400 & 6 & $5,370-484$ & UG/TGA & 250 & $04 / 22 / 82$ & 300 & 120 & 4 & P & \\
\hline $35 \mathrm{SAC} 1$ & Multnomah County & 1984 & 310 & 500 & 10 & 500 & 5 & $S, 442-487$ & $\mathrm{UG} / \mathrm{TGA}$ & 226 & $03 / 23 / 84$ & 500 & 133 & 4 & $\mathbf{P}$ & \\
\hline $35 \mathrm{CD} 1$ & Mobile Village & 1968 & 305 & 330 & 14 & 327 & $8-10$ & $P, 165-324$ & $\mathrm{UG} / \mathrm{TGA}$ & 153 & $08 / 28 / 68$ & 216 & 64 & 8 & $\mathbf{P}$ & \\
\hline
\end{tabular}




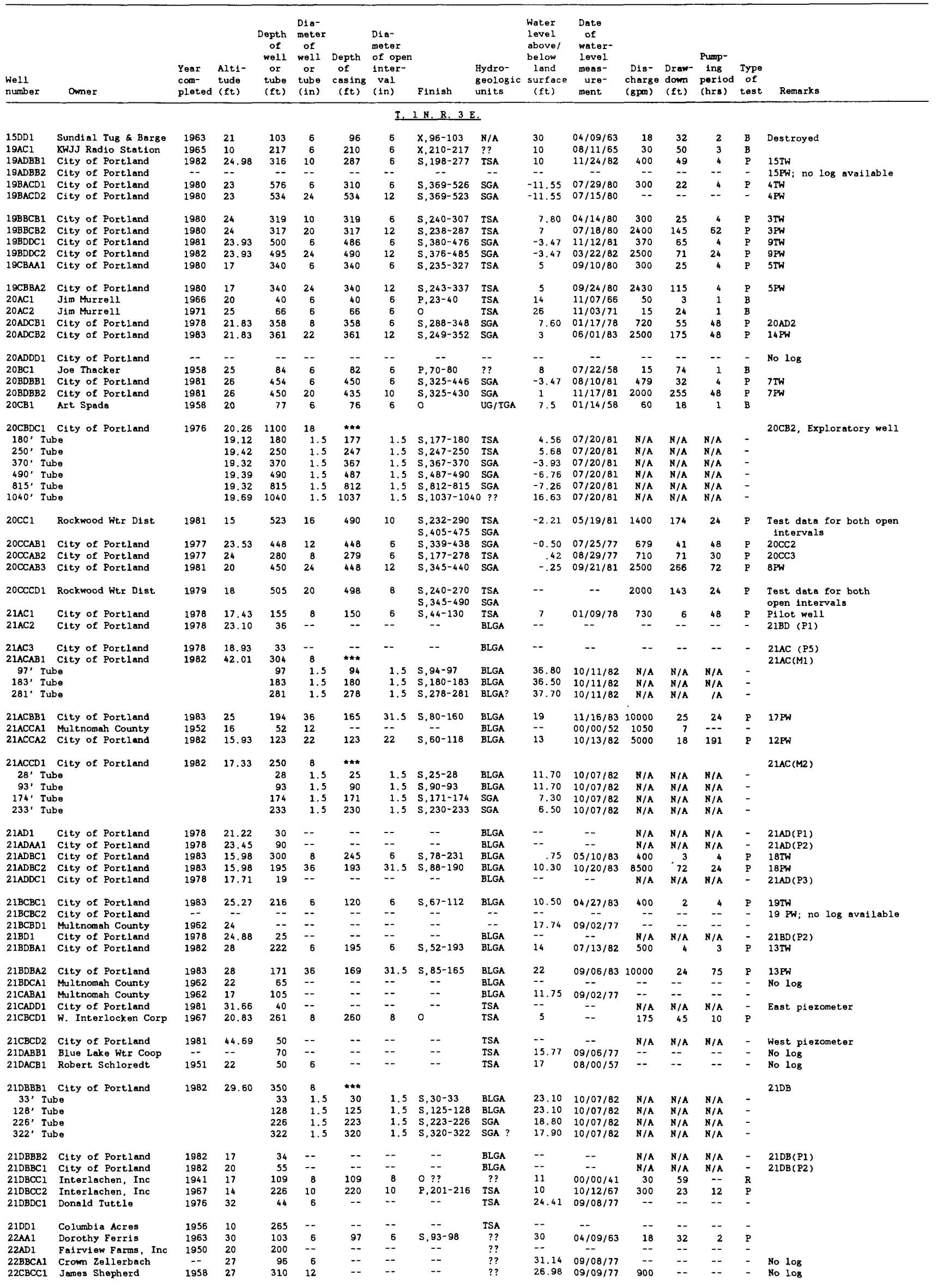




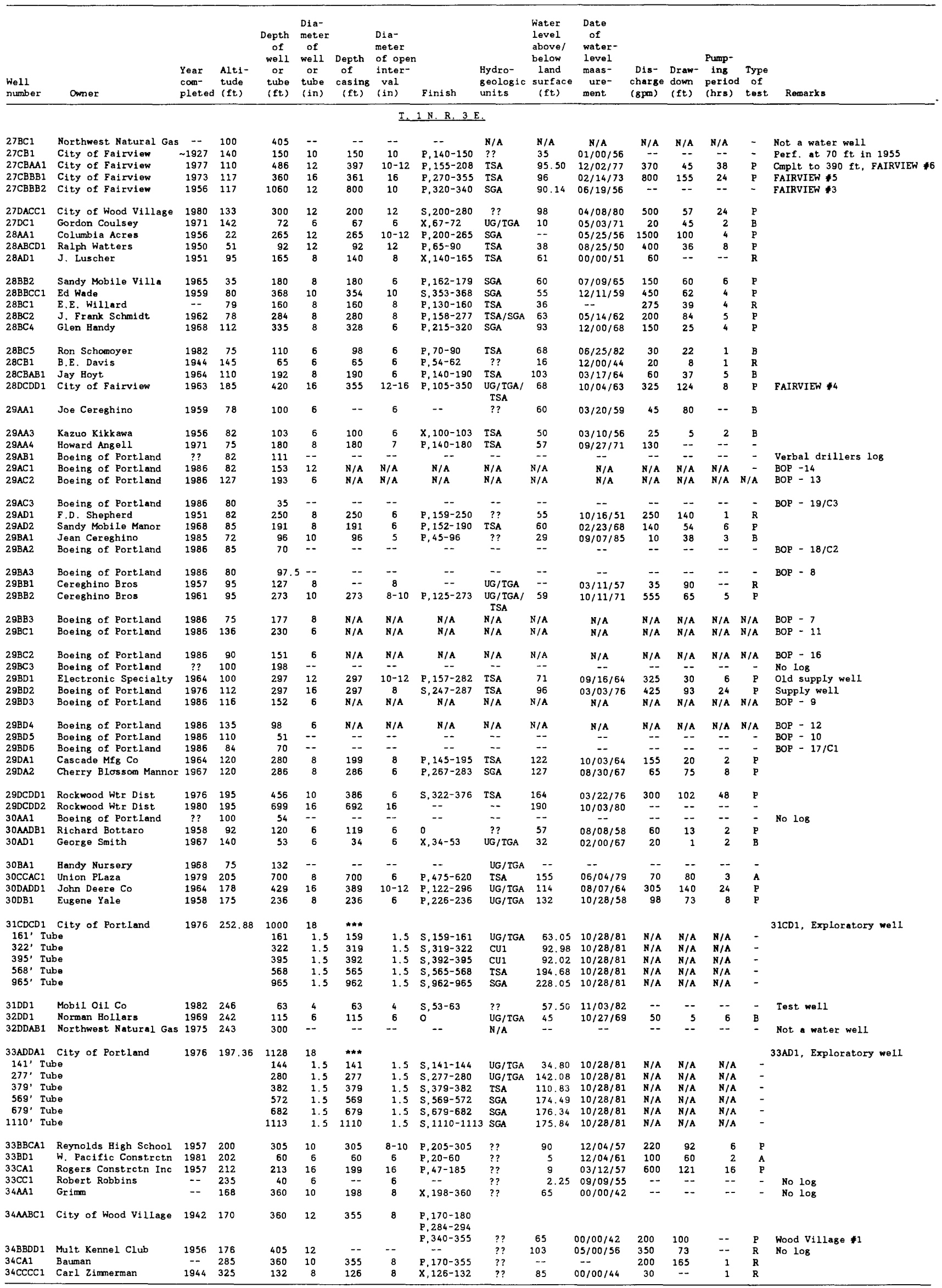




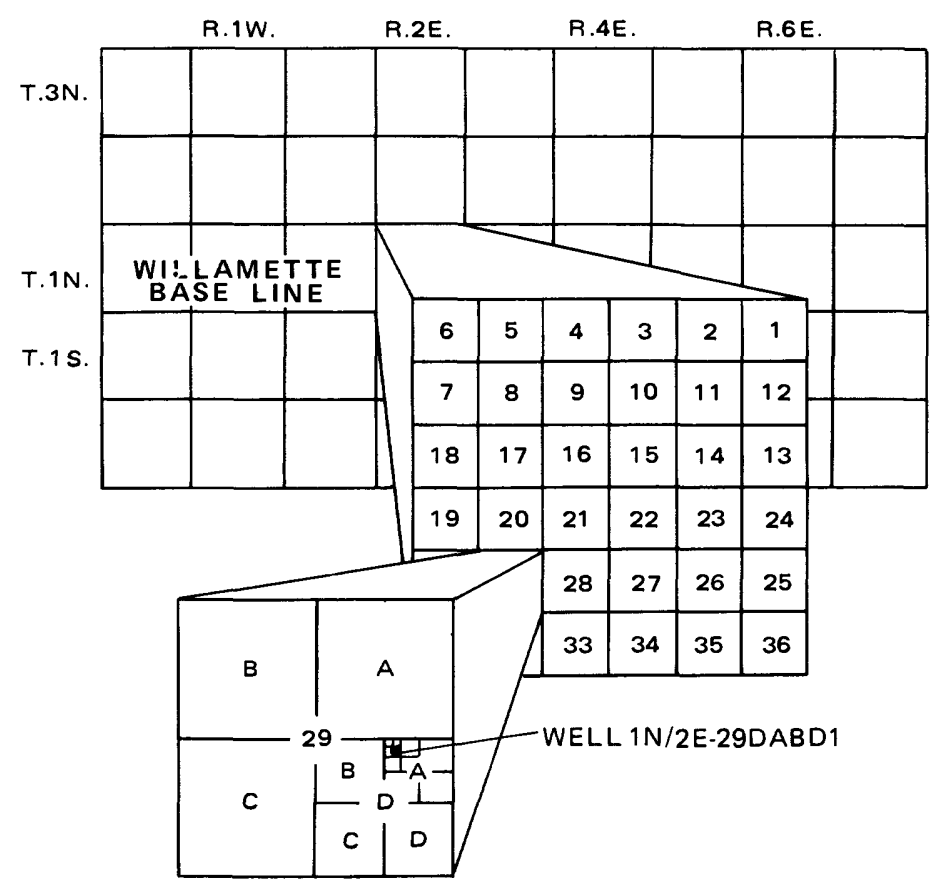

Figure 2.--Well-numbering system.

Many studies have contributed to our current understanding of the volcanic and sedimentary processes that have taken place in this region. A generalized stratigraphy of the area, as modified from the work of others (see references) and from data collected in this investigation, is summarized in figure 3. The surface geology in the study area is shown on sheet 1 (modified after Trimble, 1963), along with a diagrammatic section of the relations of the various units described in this study.

The reader is referred to the list of selected references for a more detailed discussion of the geologic history and stratigraphy of the area.

\section{older Rocks}

Older sedimentary and volcanic rocks underlie the sedimentary hydrogeologic system described in this report and are exposed outside the study area. The older rock sequences include the Skamania Volcanics, Columbia River Basalt Group, and Rhododendron Formation. These formations range from late Eocene to late Miocene in age (fig. 3).

Deformation of these older rocks created a broad structural basin referred to informally as the Portland Basin (Beeson and others, 1985). This basin is bounded, in general, by the Tualatin Mountains to the west and the Cascade Range to the east (Trimble, 1963). The northern and southern limits of the basin are not as clearly defined. Data from deep wells indicate that the thickness of sedimentary deposits in the Portland Basin may exceed 1,300 feet. However, the shape of the basin and the thickness and extent of the older rocks are unknown. 


\begin{tabular}{|c|c|c|}
\hline SYSTEM & SERIES & STRATIGRAPHIC UNIT \\
\hline \multirow[b]{3}{*}{ QUATERNARY } & Holocene & Alluvium \\
\hline & \multirow[b]{2}{*}{ Pleistocene } & Sand, gravel, silt, and clay \\
\hline & & $\begin{array}{l}\text { Boring Lava and } \\
\text { Volcanic rocks of the } \\
\text { High Cascade Range }\end{array}$ \\
\hline \multirow{8}{*}{ TERTIARY } & Pliocene & \\
\hline & & Troutdale Formation \\
\hline & \multirow{4}{*}{ Miocene } & $\{$ Sandy River Mudstone \\
\hline & & Rhododendron Formation \\
\hline & & Columbia River Basalt group \\
\hline & & \multirow[t]{3}{*}{ Skamania Volcanics } \\
\hline & Oligocene & \\
\hline & Eocene & \\
\hline
\end{tabular}

Figure 3.--Generalized stratigraphic correlation chart of the regional area. Modified from Tolan and Beeson (1984, 1985); Swanson (1986), including interpretations of Trimble (1963); Wise (1970); Waters (1973); Hammond (1979, 1980); Anderson (1980); Priest and others (1982).

Skamania Volcanics are exposed northeast of the study area along the south shore of Lady Island and along the north shore of the Columbia River (Trimble, 1963). The formation may underlie the northeast portion of the study area at depths below existing wells. Rocks of generally low permeability may form part of a hydrogeologic boundary for the aquifer system described in this report.

Flows of the Columbia River Basait Group underlie the study area, but their thickness and extent are not well defined due to a lack of deep wells in the area. The Columbia River Basalt Group is interpreted to be present at a depth of 683 feet below sea leve1 in a we11 (1N/3E-27CBBB1) in the eastern part of the study area (Hogenson and Foxworthy, 1965). On the southwestern edge of the study area, Piper (1942) indicated that at least 400 feet of the Columbia River Basalt Group underlies 1,300 feet of sediments in the Ladd well (1N/1E-36ADCD1). The top of the Columbia River Basalt Group at that well is at an altitude of 1,082 feet below sea level. More than 1,100 feet of sediment younger than the Columbia River Basalt Group was logged in a we11 (1N/3E-20CBDC1) in the north-central part of the study area (Willis, 1977; Hoffstetter, 1984). The altitude of the bottom of the well is 1,080 feet below sea level.

Flow units of the Columbia River Basalt Group have not been utilized as aquifers within the study area because of their depth within the basin. Elsewhere, at the margins of the basin, flow units of the Columbia River Basalt Group are used as aquifers.

The Rhododendron Formation is exposed southeast of the study area in the Sandy River and Bull Run River. This formation may or may not underlie the aquifer system described in this report. Lahars present within the lower Troutdale Formation to the east of the study area have been correlated with rocks of the Rhododendron Formation (Tolan and Beeson, 1984a). 
Sandy River Mudstone and Troutdale Formation

The most areally extensive hydrogeologic units in the study area occur within the Sandy River Mudstone and the Troutdale Formation. Claystone, siltstone, and sandstone beds of the Sandy River Mudstone and sandstone and conglomerate beds of the Troutdale Formation overlie flows of the Columbia River Basalt Group in the Portland Basin (Trimble, 1963). These sediments represent a large thickness of lacustrine and fluvial material, derived from sources to the east of the study area and deposited within an active structural basin (Trimble, 1963; Beeson and others, 1985). The Troutdale Formation and the Sandy River Mudstone range in age from late Miocene to Pliocene (fig. 3).

Two facies of the Troutdale Formation have been described by Tolan and Beeson (1984a). The ancestral Columbia River facies is composed chiefly of fluvial conglomerates containing foreign clasts such as quartzite and granite deposited by the Columbia River. Locally derived clasts deposited by Cascadian streams form what is termed the Cascadian stream facies. The distribution of these two facies of the Troutdale Formation is shown in figure 4.

The ancestral Columbia River facies of the Troutdale Formation has been subdivided into two distinct lithologic members, based on the onset of highalumina basalt volcanism in the lower Columbia River Gorge area (Tolan and Beeson, 1984a). The lower member is described as primarily quartzitebearing, basaltic conglomerates and micaceous, arkosic sand. The upper member is characterized by the presence of basaltic glass and clasts of high-alumina basalt composition (Tolan and Beeson, 1984a; Swanson, 1986). This material forms vitric-1ithic sandstones and conglomerates.

Comparison of geochemical analyses of drill cuttings from the study area and analyses of outcrop samples from the lower Columbia River Gorge area indicate that the transition between upper and lower members of the ancestral Columbia River facies can be identified in the study area

(Swanson, 1986). This correlation establishes the stratigraphic position of some of the hydrogeologic units described in this report.

Coarse-grained material of the Troutdale Formation generally forms good aquifers within the study area and elsewhere in the region. The Sandy River Mudstone is not generally noted for productive aquifers. However, coarsegrained layers of the Sandy River Mudstone do form aquifers in the study area. Outside the study area, detailed mapping of Troutdale Formation and Sandy River Mudstone is not presently available. Future geologic mapping may allow interpretation of their depositional relations which will provide new information on the extent and thickness location of water-yielding sediments.

\section{Boring Lava}

Boring Lava is exposed in the Portland area as numerous volcanic vents, such as Mount Tabor and Rocky Butte (fig. 1). High-alumina basalt of the Boring Lava intruded Troutdale Formation and Sandy River Mudstone sediments and was erupted onto an extensively eroded surface of the Troutdale Formation (Trimble, 1963). These volcanic vents truncate hydrogeologic units in the southwestern part of the study area (sheets 2-4). East of the study area, high-alumina basalt flows are found intercalated with and overlying the upper part of the Troutdale Formation (Williams, 1916; Lowry and Baldwin, 1952; Tolan, 1982; Tolan and Beeson, 1984a). 


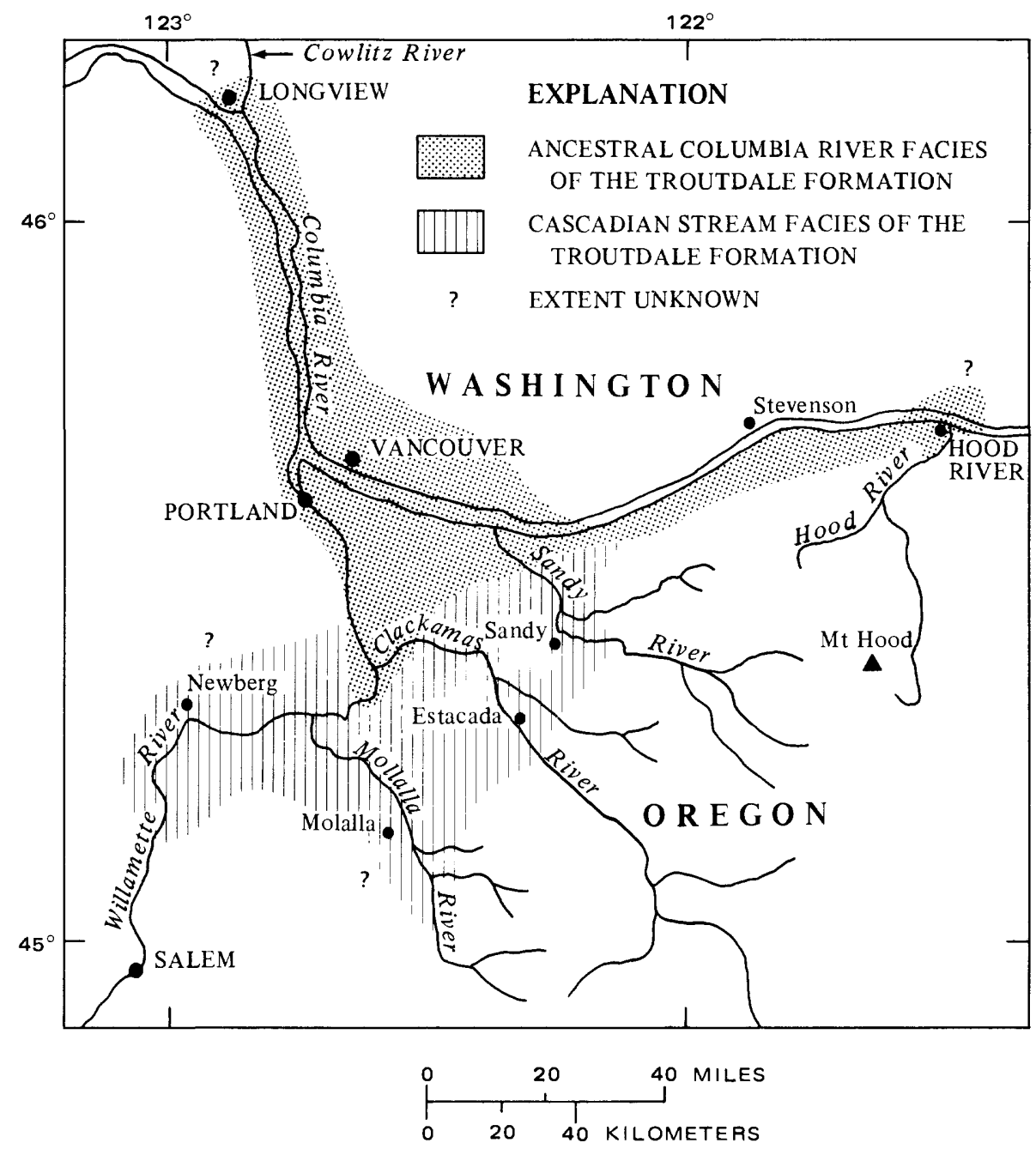

Figure 4.--Facies distribution of the Troutdale Formation (from Tolan and Beeson, 1984b).

Boring Lava of the Portland area and volcanic rocks of the High Cascade Range are informally grouped together on the basis of similar age and lithology (Peck and others, 1964). These rocks are also informally referred to as high-alumina basalt, on the basis of majoroxide analyses (Tolan and Beeson, 1984a). The age range of these highalumina basalts is late Pliocene to Pleistocene, on the basis of stratigraphic relations and age dating of basalt flows (Tolan, 1982; Tolan and Beeson, 1984a; Wise, 1969; Hammond, 1979).

Significant amounts of vitric sand (basaltic glass) and basaltic clasts of high-alumina basalt composition (Swanson, 1986) form excellent aquifers within the upper part of the Troutdale Formation in the study area. This material was derived from interaction of high-alumina basalt flows with the ancestral Columbia River in the lower Columbia River Gorge area (Tolan and Beeson, 1984b).

Ground water in the Boring Lava occurs mainly in perched zones above the regional water table (Hogenson and Foxworthy, 1965). Wells in these zones have generally small yields. Boring Lava flows were encountered between 23 and 206 feet above sea level in a wel1 (1N/2E-21CCCD1) just west of Rocky Butte (sheet 1). These flow units yielded no ground water. 


\section{Quaternary Deposits}

The detail of recent geologic events in the Portland area is not thoroughly understood. Regional tectonic uplift, volcanic activity, interglacial changes in sea level, and failure of glacial ice dams (upstream in the Columbia River Drainage system) combined to create many periods of erosion, channel incision, and deposition during Pleistocene time. Flood deposits and terrace deposits of sand, silt, gravel, and clay have accumulated to several hundred feet in thickness in the Portland area. Mudflows and other volcanic debris were deposited from nearby volcanic centers. Weathering and erosion have modified the original surface of these Quaternary deposits.

Pleistocene channel segments, cut by the ancestral Columbia River and filled with sand and gravel deposits, have been identified on the basis of seismic reflection profiling and interpretation of well data (Willis, 1978; McFarland and others, 1982; Hoffstetter, 1984).

\section{HYDROGEOLOGIC UNITS}

In this report, the sequence of Tertiary and Quaternary sediments is divided into distinct hydrogeologic units (aquifers and confining units) on the basis of their water-bearing properties. An aquifer is defined as a water-bearing layer of rock that will yield a usable quantity of water to a well or spring. Confining units are composed of relatively fine-grained sediments which have distinctly lower permeability than adjacent aquifers. Hydrogeologic units may cross known stratigraphic boundaries where coarse or fine-grained material of two formations are grouped together, forming one aquifer or confining unit. Aquifers and confining units also may occur as local features or may exist as regionally extensive units.

Five hydrogeologic units have been identified in the East Portland study area (Willis, 1977, 1978; Hoffstetter, 1984); these units can be correlated with sediments identified as the Troutdale Formation and the underlying Sandy River Mudstone. These hydrogeologic units are informally referred to, from oldest to youngest, as the (1) sand and gravel aquifer, (2) confining unit 2, (3) Troutdale sandstone aquifer, (4) confining unit 1 , and (5) unconsolidated gravel/Troutdale gravel aquifer. Only a part of the unconsolidated gravel/Troutdale gravel aquifer unit is correlative with the Troutdale Formation; see description in text. Correlation of informal unit names used in this report with those used by previous workers is shown in figure 5 .

Near the area of the Columbia River floodplain, these units strike generally north-northwest and dip gently (less than 2 degrees) southwest toward the interpreted center of the basin. Complex structure on the north and east margins of the Portland Basin (Davis, 1988; and Swanson, 1986) and extensive erosion in the Blue Lake area combine to create irregular surfaces and thicknesses of the five hydrogeologic units in this area. Units may also be truncated or more steeply dipping in these areas (sheets 2 to 6 ). A cross section along the south shore of the Columbia River shows some of these features (sheet 1).

Hydrogeologic units included in the Troutdale Formation and Sandy River Mudstone have been exposed to erosion during periods of intermittent deposition and incision of the ancestral Columbia, Sandy, and Clackamas Rivers during Pleistocene and Holocene time (Trimble, 
1963). Two paleochannel segments have been identified on the south shore of the Columbia River (Willis, 1978; McFarland and others, 1982; Hoffstetter, 1984). The deposits that fill those channel segments form aquifers of limited extent (fig. 5) and are informally referred to as the (1) Blue Lake gravel aquifer and (2) Columbia River sand aquifer.

The Columbia River floodplain is mantled with fine-grained surface deposits, which overlie hydrogeologic units of the study area. These deposits are primarily the result of intermittent flooding of the Columbia River and are informally referred to as overbank deposits in this study (fig. 5).

\begin{tabular}{|c|c|c|c|c|}
\hline \multirow{2}{*}{ SYSTEM } & \multirow{2}{*}{ SERIES } & \multicolumn{3}{|c|}{ HYDROGEOLOGIC UNIT } \\
\hline & & WILLIS; 1977,1978 & HOFFSTETTER; 1984 & THIS REPORT \\
\hline \multirow{4}{*}{ QUATERNARY } & \multirow{3}{*}{ Pleistocene } & $\begin{array}{l}\text { Unnamed clayey } \\
\text { and sandy silt }\end{array}$ & $\begin{array}{l}\text { Recent floodplain } \\
\text { deposits }\end{array}$ & Overbank deposits \\
\hline & & Blue Lake aquifer & Blue Lake aquifer & Blue Lake gravel aquifer \\
\hline & & Columbia River sands & $\begin{array}{l}\text { Columbia River sands } \\
\text { aquifer }\end{array}$ & $\begin{array}{l}\text { Columbia River sand } \\
\text { aquifer }\end{array}$ \\
\hline & $-?-?-?-$ & Troutdale gravel aquifer & Parkrose gravel aquifer & Unconsolidated gravel/ \\
\hline \multirow{5}{*}{ TERTIARY } & \multirow{4}{*}{ Pliocene } & & & Troutdale gravel aquifer \\
\hline & & Unnamed aquitard & Parkrose aquitard & Confining unit 1 \\
\hline & & $\begin{array}{l}\text { Troutdale sandstone } \\
\text { aquifer }\end{array}$ & $\begin{array}{l}\text { Troutdale sandstone } \\
\text { aquifer }\end{array}$ & $\begin{array}{l}\text { Troutdale sandstone } \\
\text { aquifer }\end{array}$ \\
\hline & & Unnamed aquitard & Rose City aquitard & Confining unit 2 \\
\hline & \begin{tabular}{|l|}
$-?-?-?-$ \\
Upper \\
Miocene
\end{tabular} & $\begin{array}{l}\text { Sandy River Mudstone } \\
\text { aquifer }\end{array}$ & $\begin{array}{l}\text { Rose City aquifer } \\
\text { Lower Rose City aquifer }\end{array}$ & Sand and gravel aquifer \\
\hline
\end{tabular}

Figure 5.--Correlation of informal hydrogeologic-unit names used in this study with those used by previous investigators.

\section{$\underline{\text { Sand and Gravel Aquifer }}$}

The sand and gravel aquifer is the lowermost hydrogeologic unit in the study area and consists of a thick section of sand, silt, gravel, and clay beds. Sand and gravel predominate at the top of the unit, grading to relatively fine-grained material near the bottom. Some lenticular deposits also are present. At depth some coarse-grained material is present, on the basis of well-log data from well 1N/2E-29DABD1 in the southwestern part of the study area. The sand and gravel aquifer underlies the entire study area. This unit may have a maximum thickness in excess of 560 feet, on the basis of 1ithologic and aquifer-test data in the southeastern part of the study area at well 1N/3E-33ADDA1 (sheet 2). 
The sand and gravel aquifer is one of the more important aquifers in the study area; however, lithologic correlation using well records is difficult because of a scarcity of wells drilled in this unit. This aquifer can be divided into two lithologic units: a relatively coarsegrained upper unit and a predominately fine-grained lower unit.

In the western part of the study area, the upper unit consists primarily of fine to medium vitric-lithic sand with minor amounts of gravel. The sand is chiefly vitric material (basaltic glass) with varying percentages of basalt and quartz sand. Minor thin lenses of greenish-blue clay to gray-brown silt and minor clasts of basaltic composition occur throughout. This upper unit is locally indurated, and thickness varies from 50-120 feet.

Toward the eastern part of the study area, the upper unit becomes thicker, more cemented, and consists primarily of basaltic clasts in a sandy matrix. These clasts consist of quartzite-bearing basaltic gravel with minor cobbles. Black vitric sand predominates near the top of the unit, forming lenses in the matrix. At depth, the sand becomes more lithic with varying percentages of quartz and basalt sand and a trace of muscovite. Minor thin lenses of gray-green clay and gray-brown silt occur near the bottom of the unit. Thickness ranges from 120 to greater than 200 feet. Cementation is common in the eastern part of the upper unit of the sand and gravel aquifer. Underlying the Blue Lake area, the upper unit of the sand and gravel aquifer has been partially eroded. The composition of the sand and gravel aquifer in this location changes over a short distance, becoming relatively fine-grained to the east. Based on limited well data, this transition may be interpreted as another type of channel fill or may represent a facies change within the sand and gravel aquifer.

In the study area, the transition between upper and lower units is gradual. In general, fine-grained material is more prevalent at depth within the sand and gravel aquifer. The lower unit is composed of lenses of fine- to coarse-grained sediment, but is predominately finegrained. Light blue-grey sandy to silty clay layers are interbedded with layers of micaceous, quartzitic, and basaltic sand. Sand and gravel of quartzitic and basaltic composition occur in lenses throughout the lower unit, but are not common.

Correlation of basaltic glass (vitric material) in the upper unit of the sand and gravel aquifer in the study area with basaltic glass clasts from outcrops in the lower Columbia River Gorge (Swanson, 1986) suggests that the upper unit is part of the informal upper member of the ancestral Columbia River facies of the Troutdale Formation (Tolan and Beeson, 1984a). On the basis of similar lithology, the fine-grained lower unit of the sand and gravel aquifer appears to be more closely related to lacustrine sediments of the Sandy River Mudstone.

\section{Confining Unit 2}

The sand and gravel aquifer unit is overlain by fine-grained material of confining unit 2 throughout most of the study area. Along the Columbia River floodplain, confining unit 2 ranges from about 0 to 100 feet in thickness. To the south and southeast, confining unit 2 becomes more than 180 feet in thickness (we11 1N/3E-31CDCD1). To the southwest, confining unit 2 thins to less than 30 feet in thickness. In the Blue Lake area, confining unit 2 dips more steeply to the west than 
is observed in the rest of the study area. Here confining unit 2 abruptly thins and disappears beneath the Blue Lake gravel aquifer (sheets 1 and 2). To the west, confining unit 2 dips more gently (less than 2 degrees). South of the floodplain, confining unit 2 dips generally to the south. Few wells penetrate this unit in this area. The top of confining unit 2 appears to be a heavily eroded surface (sheet 2).

Confining unit 2 acts as a leaky confining layer (Willis, 1978) between the upper unit of the sand and gravel aquifer and the overlying Troutdale sandstone aquifer. Greyish-olive clay with minor silt and thin lenses of fine-to medium-grained basaltic sand form the predominant lithology of this unit. A claystone occurs near the bottom of confining unit 2 in most of the study area. Fine-grained sediments of confining unit 2 are interpreted as lacustrine beds, deposited in a closed basin that existed for a short period of time because of local tectonic deformation (Trimble, 1963).

\section{Troutdale Sandstone Aquifer}

Sand, sandstone, and conglomerate that compose the Troutdale sandstone aquifer overlie fine-grained material of confining unit 2 . The Troutdale sandstone aquifer averages about 100 feet in thickness in the study area, except where it has been partly or completely eroded. South of the floodplain area, the Troutdale sandstone aquifer dips southwest in the direction of City of Portland exploratory well (1N/2E-29DABD1); at this location the top of the Troutdale sandstone aquifer is at 387 feet below sea level. Approximately 0.5 miles north of this well, another well (1N/2E-21CCCD1) fails to penetrate the top of the Troutdale sandstone aquifer. The bottom-hole altitude is 408 feet below sea level, and it is possible that the Troutdale sandstone aquifer is present at a greater depth.

In the northeastern part of the study area, south of Blue Lake, an exposed ridge of sandstone trends west-northwest and dips about 12 to 14 degrees southwest. This ridge is interpreted to be part of the Troutdale sandstone aquifer on the basis of geochemical and lithologic similarities and stratigraphic relations. The change in dip from less than 2 degrees (west of Blue Lake) to about 12 to 14 degrees (south of Blue Lake) is interpreted as a homoclinal feature (Swanson, 1986). The Troutdale sandstone aquifer crops out south of Blue Lake and to the south and east of Fairview Lake. Complex structure and extensive erosion in this area make an interpretation of the Troutdale sandstone aquifer thickness and upper surface difficult to describe and map (sheet 3 ). North of Blue Lake, the Troutdale sandstone aquifer is thought to be completely removed by erosion. Large isolated sandstone blocks are seen at the surface and noted within materials of the Blue Lake gravel aquifer.

The Troutdale sandstone aquifer thins to less than half its average thickness (about 100 feet) in the area of a paleochannel segment in the northwestern part of the study area (sheet 3 ). Channel erosion does not appear to be a reasonable hypothesis for thinning of the Troutdale sandstone aquifer in this location because confining unit 1 , which overlies the Troutdale sandstone aquifer, does not appear to have been completely removed by channel erosion leaving the Troutdale sandstone aquifer intact in this location (sheet 3 ). The thickness of the Troutdale sandstone aquifer in this location may be the result of numerous variables such as minor faulting or perhaps deposition on an extensively eroded surface (of confining unit 2). 
The Troutdale sandstone aquifer is the most lithologically unique hydrogeologic unit in the study area; it consists of two distinct units. Sand, sandstone, and minor thin silty-clay lenses of the upper unit compose two-thirds of the Troutdale sandstone aquifer; a conglomerate, composed chiefly of basaltic gravel, forms the lower unit. At the northwestern edge of the study area, the lower unit of the Troutdale sandstone aquifer gradually becomes composed of a greater percentage of sand versus gravel-sized material.

Sand and sandstone of the upper unit consist mainly of relatively clean, moderate - to well-sorted, angular to sub-rounded black basaltic glass (sideromelane). Local alteration of sideromelane grains to palagonite (Trimble, 1963) has resulted in formation of a cementing agent in the Troutdale sandstone aquifer unit. Thin blue to blue-green silty clay lenses occur in the upper one-half of this unit.

Basaltic glass and clay of the upper unit of the Troutdale sandstone aquifer exhibit a relatively unique signature on natural gamma logs completed for some of wells in the study area. The sequence of basaltic glass-clay-basaltic glass at the top of the Troutdale sandstone aquifer correlates with corresponding low-high-low natural gamma activity. This feature is a positive correlation tool for indicating the top of the Troutdale sandstone aquifer in the study area.

The lower unit of the Troutdale sandstone aquifer consists mainly of quartzite-bearing basalt conglomerate with a silty-to-sandy matrix composed primarily of vitric-lithic material. Minor lenses of vitriclithic sand occur, but are not as common. The cemented gravels of the basalt conglomerate are well rounded and poorly sorted.

The Troutdale sandstone aquifer unit is considered to be part of the upper member of the ancestral Columbia River facies of the Troutdale Formation, based on lithological and geochemical similarity of well cuttings in the study area to outcrop samples in the lower Columbia River Gorge (Swanson, 1986).

\section{Confining Unit 1}

The Troutdale sandstone aquifer unit is overlain by fine-grained sediments of confining unit 1 , which is found throughout most of the study area, except where removed by erosion. Estimated thickness ranges from 0 to 150 feet in the study area, averaging about 100 feet west of the Blue Lake area underlying the Columbia River floodplain. The absence of confining unit 1 north and south of Blue Lake possibly is the result of erosion. In the northwestern part of the study area, confining unit 1 has been partially removed by erosion of an ancestral Columbia River as interpreted from well cuttings in that area.

At the site of well 1N/3E-33ADDAl, fine-grained material of confining unit 1 is not described in the geologic log of the well. A coarser-grained unit (indistinct from the unconsolidated gravel/Troutdale gravel aquifer acts as a confining unit between the Troutdale sandstone aquifer and unconsolidated gravel/Troutdale gravel aquifer. At this location, the confining unit 1 is noted on the contour maps as "not present," although it may be present as a coarser-grained facies (sheet 4 ). 
Dark olive-grey to grey-brown sand, silt, and clay are the predominant lithology of confining unit 1 . Black vitric sand or sandstone occurs in beds ranging from 5 to 15 feet in thickness. These vitric beds occur near the top of confining unit 1 in the east part of the study area and near the bottom of the unit to the west. Most well logs and geophysical logs in the study area indicate that a clay with relatively high natural gamma activity occurs at the bottom of this unit.

Sediments of confining unit 1 appear to be of lacustrine origin similar to the sediments observed in confining unit 2, probably deposited in a closed basin that existed for a relatively short period of time.

\section{Unconsolidated Gravel/Troutdale Gravel Aquifer}

The unconsolidated gravel/Troutdale gravel aquifer overlies confining unit 1 in most of the study area, except where it has been removed by erosion in the northwestern and northeastern parts of the study area. The unconsolidated gravel/Troutdale gravel aquifer consists of gravels of the Troutdale Formation of late Pliocene age and also younger Pleistocene gravels, which are undifferentiated in well-log data. Hogenson and Foxworthy (1965) used several criteria to distinguish Pleistocene gravels from gravels of the Troutdale Formation. Their observations indicated that, in general, unconsolidated Pleistocene gravels overlie cemented gravels of the Troutdale Formation. However, cementation appears to occur in both units in the study area (as noted in well reports and geologic logs) and therefore cannot be used to differentiate them. It has also been observed that Pleistocene gravels are composed mainly of locally derived basaltic clasts, while Troutdale gravels have been noted to consist of as much as 30 percent foreign clasts such as quartzite or granitic rocks (Trimble, 1963; Cole, 1982). In drillers' reports, clast composition is rarely recorded. Therefore, for the purposes of this study, these Pleistocene gravels are informally included in the unconsolidated gravel/Troutdale gravel aquifer.

The unconsolidated gravel/Troutdale gravel aquifer ranges in thickness from about 0 to 580 feet, gradually increasing in thickness from east to west in the area of the well field. The unconsolidated gravel/Troutdale gravel aquifer consists mainly of Troutdale gravels in the well field area; the unit strikes generally east to west. Elsewhere its thickness increases to the south, where a greater percentage of younger Quaternary terrace gravels and flood deposits are grouped with gravels of the upper part of the Troutdale Formation to form what is termed the unconsolidated gravel/Troutdale gravel aquifer. The upper surface of this unit crops out south of the Columbia River floodplain; therefore, the altitude of the top of the Troutdale gravel aquifer unit is contoured only on the floodplain (sheet 5).

The Troutdale gravels consist mainly of pebbly to cobbly clastsupported conglomerate with a silty to sandy matrix. Sixty to eighty percent of clasts are composed of sub- to well-rounded basalt, with the remainder composed of quartzite and other foreign clasts. The matrix consists of olive-gray to brown sand, silt, and clay. Thin lenses of material similar to the matrix occur intermittently throughout the unit. 


\section{Blue Lake Grave1 Aquifer}

The Blue Lake gravel aquifer consists of coarse channel deposits of the ancestral Columbia River. It forms an aquifer of limited extent north of Blue Lake in the northeastern part of the study area (sheet 6). An aquifer of similar lithology and extent is present beneath the north shore of the Columbia River near Camas-Washougal, Washington (Mundorff, 1964). The estimated thickness of the Blue Lake gravel aquifer ranges from about 60 to 220 feet in the study area (sheet 6).

The Blue Lake gravel aquifer is composed primarily of boulder-, cobble - and gravel-sized clasts in a minor matrix of clayey to sandy silt. The coarse gravel consists of 60- to 95-percent basalt, with the balance composed of quartzite, granite, and diorite. Minor sandstone cobbles and boulders also are present, along with traces of claystone pebbles and lenses. The unit is clast supported, averaging 80- to 95-percent gravel and 5- to 20-percent matrix. The Blue Lake gravel aquifer becomes siltier with depth.

The southern boundary of this unit is the west-northwest trending sandstone ridge south of Blue Lake. North of the ridge, older hydrogeologic units, including the confining unit 1, Troutdale sandstone aquifer, and part of confining unit 2 and the sand and gravel aquifer, are thought to have been removed by erosion. The stratigraphy of the area is difficult to interpret east of Blue Lake, because of lack of well data. Well data from approximately 2 miles east of Blue Lake have been variously interpreted as representing part of the Sandy River Mudstone and Troutdale Formation (Hogenson and Foxworthy, 1965; Willis, 1978).

\section{Columbia River Sand Aquifer}

The Columbia River sand aquifer fills the lower part of a Pleistocene channel segment of the ancestral Columbia River (McFarland and others, 1982; Willis, 1978; Hoffstetter, 1984) in the northwestern part of the study area. This paleochannel segment has a depth of more than 300 feet (Hoffstetter, 1984), and erosion has removed part of the unconsolidated gravel/Troutdale gravel aquifer and confining unit 1, as indicated by well data in the study area. More than 250 feet of this channel fill was encountered in well $1 \mathrm{~N} / 2 \mathrm{E}-15 \mathrm{BCACl}$. This aquifer is of limited extent and follows a general west-northwest trend near the present-day Columbia River (sheet 6).

The Columbia River sand aquifer is composed of gray to gray-brown, fine-grained, commonly quartz-rich basaltic sand that is relatively clean. Traces of silt, siltstone and sandstone fragments, muscovite flakes, wood, shells, and coarse sand and gravel occur throughout the aquifer. The unit generally becomes siltier with depth, but in some drill holes the bottom 10 to 40 feet of the Columbia River sand aquifer contains a coarse sand and gravel layer with minor boulders.

\section{Overbank Deposits}

Overbank deposits occur in the study area as the uppermost unit on the Columbia River floodplain. In general, the thickness of these fine-grained deposits is greatest near the modern shoreline of the Columbia River and thins to zero at the southern limit of the floodplain (sheet 6). This unit 
thickens in the area of the Columbia River sand aquifer in the northwestern part of the study area (sheet 6 ). Here the sandy silt deposits in the upper part of the paleochannel are unsaturated and are included in the fine-grained alluvial material of the overbank deposits.

Overbank deposits consist primarily of light olive-brown to dusky yellow-brown silty clay and brown to grey-brown fine-grained sandy silt. These deposits are chiefly the result of intermittent flooding of the Columbia River.

\section{SUMMARY}

The lithology, thickness, and extent of a hydrogeologic system within sediments of the Portland Basin are described, on the basis of interpretation of geologic logs, natural gamma logs, aquifer test data, and selected driller reports. Eight hydrogeologic units are represented and correlated with geologic units that have been mapped in the region. The thickness and extent of each hydrogeologic unit are the result of river processes and basin development. Understanding the stratigraphy of the system and its relation to the regional geologic setting strengthens the knowledge of how ground water flows through the system.

The eight hydrogeologic units are distinct and can be traced outside the study area. Units that are part of the Troutdale Formation and Sandy River Mudstone include the sand and gravel aquifer, confining unit 2, Troutdale sandstone aquifer, confining unit 1 , and part of the unconsolidated gravel/Troutdale gravel aquifer. The remaining units are associated with Quaternary processes of the Columbia River and are referred to as the Blue Lake gravel aquifer, Columbia River sand aquifer, and overbank deposits. 


\section{SELECTED REFERENCES}

Allen, J. E., 1932, Contributions to the structure, stratigraphy, and paleontology of the lower Columbia River Gorge [M.A. thesis]: Eugene, Oregon, University of Oregon, $96 \mathrm{p}$.

1975, Volcanoes of the Portland area, Oregon: Oregon Department of Geology and Mineral Industries, The Ore Bin, v. 37, no. 9., p. 145157.

Anderson, J. L., 1978, The stratigraphy and structure of the Columbia River basalt in the Clackamas River drainage [M.S. thesis]: Portland, Oregon, Portland State University, $136 \mathrm{p}$.

1980, Pomona Member of the Columbia River Basalt Group: Oregon Department of Geology and Mineral Industries, Oregon Geology, v. 42 , no. 12 , p. $115-125$.

Armentrout, J. M., Hul1, D. A., Beaulieu, J. D., and Rau, W. W., 1983, Correlation of Cenozoic stratigraphic units of western Oregon and Washington: Department of Geology and Mineral Industries, Oil and Gas Investigation 7,90 p., 1 pl.

Baldwin, E. M., 1981, Geology of Oregon, 3rd edition: Dubuque, Iowa, Kendall/Hunt Publishing Company, 147 p.

Beeson, M. H., Fecht, K. R., Reidel, S. P., and Tolan, T. L., 1985, Regional correlations within the Frenchman Springs Member of the Columbia River Basalt Group: New insights into the middle Miocene tectonics of northwestern Oregon: Oregon Geology, v. 47, no. 8, p. 87-96.

Berg, J. W., Jr., King, J. M., and Carlson, P. R., 1966, Seismic reflection studies of buried channels off the Columbia River:

Oregon Department of Geology and Mineral Industries, The Ore Bin, v. 28, no. 8, p. $145-151$.

Cole, D. L, 1983, A preliminary investigation of the lithological characteristics of the Troutdale Formation in a portion of Camas, Sandy, Washougal and Bridal Veil Quadrangles [M.S. thesis]: Portland, Oregon, Portland State University, $69 \mathrm{p}$.

Dames and Moore, 1986, Interim status report, Ground-water monitoring project, Pretreatment plant surface impoundment, Boeing of Portland, Facility: Report to Boeing, Portland, Oregon.

Davis, S. A., 1988, An analysis of the eastern margin of the Portland Basin using gravity surveys [M.S. thesis]: Portland, Oregon, Portland State University, 135 p.

Foxworthy, B. L., Hogenson, G. M., and Hampton, E. R., 1964, Records of wells and springs, water levels, and chemical quality of ground water in the East Portland area, Oregon: Oregon Ground-Water Report 3, 79 p., 1 pl.

Griffin, W. C., Watkins, F. A., Jr., and Swenson, H. A., 1956, Water resources of the Portland, Oregon, and Vancouver, Washington, area: U.S. Geological Survey Circular 372, 45 p., 2 pls. 
Hammond, P. E., 1979, A tectonic model for evolution of the Cascade Range, in Armentrout, J. M., Cole, M. R., and Terbest, H., Jr., eds., Cenozoic paleography of the western United States: Pacific Coast Paleogeography Symposium 3, Anaheim, California, Society of Economic Paleontologists and Mineralogists, Pacific Section, p. $219-237$.

1980, Reconnaissance geologic map and cross sections of southern Washington Cascade Range, latitude $45^{\circ} 30^{\prime}-47^{\circ} 15^{\prime}$ N., longitude $120^{\circ} 45^{\prime}-122^{\circ} 22^{\prime}$ W. : Geology Department, Portland State University, Portland, Oregon.

Hart, D. H., and Newcomb, R. C., 1965, Geology and ground water of the Tualatin Valley, Oregon: U.S. Geological Survey Water-Supply paper 1697,169 p., 3 pls.

Hodge, E. T., 1938, Geology of the lower Columbia River: Geological Society of America Bulletin, v. 49, no. 6, p. 831-930.

Hoffstetter, W. F., 1984, Geology of the Portland well field: Oregon Geology, v. 46, no. 6, p. 63-67.

Hogenson, G. M., and Foxworthy, B. L., 1965, Ground water in the East Portland area, Oregon: U.S. Geological Survey Water-Supply Paper $1793,78 \mathrm{p}$.

Landau Associates, Inc., 1986, Boeing of Portland, Phase I investigation: Report to Boeing, Portland, Oregon.

1987a, Quarterly status report, Boeing of Portland, Phase I investigation; First quarter: Report to Boeing, Portland, Oregon.

1987b, Quarterly status report, Boeing of Portland, Phase I investigation; Second quarter: Report to Boeing, Portland, Oregon.

Lowry, W. D., and Baldwin, E. M., 1952, Late Cenozoic geology of the lower Columbia River Valley, Oregon and Washington: Geological Society of America Bulletin, v. 63, no. 1., p. 1-24, 1 pl.

McFarland, W. D., Luzier, J. E., and Willis, R. F., 1982, Well field hydrogeology and simulation modeling, Portland, Oregon: EOS, Transactions, American Geophysical Union Abstracts, v. 63, no. 45, p. 933.

Mundorff, M. J., 1964, Geology and ground-water conditions of Clark County, Washington, with a description of a major alluvial aquifer along the Columbia River: U.S. Geological Survey Water-Supply Paper 1600, 268 p., 3 pls.

Pardee, J. T., 1910, The Glacial Lake Missoula: Journal of Geology, v. 18 , no. 4, p. $376-386$.

Peck, D. L., Griggs, A. B., Sch1icker, H. G., We11s, F. G., and Dole, H. M., 1964, Geology of the central and northern parts of the western Cascade Range in Oregon: U.S. Geological Survey Professional Paper 449,56 p. 
Piper, A. M., 1942, Ground-water resources of the Willamette Valley, Oregon: U.S. Geological Survey Water-Supply Paper 890, 194 p., 10 pls.

Priest, G. R., Beeson, M. H., Gannett, M. W., and Berri, D. A., 1982, Geology, geochemistry and geothermal resources of the old Maid Flat area, Oregon, in Priest, G. R., and Vogt, B. F., eds., Geology and geothermal resources of the Mount Hood area, Oregon: Oregon Department of Geology and Mineral Industries Special Paper 14, p. $16-30$.

Sverdrup, Parce1, and Associates, Inc., 1971, Preliminary foundation investigation: I-205 Columbia River bridge south channel extension, Portland, Oregon-Vancouver, Washington: Portland, Oregon, $\mathrm{CH} 2 \mathrm{M}$ Hill.

1974, Preliminary foundation investigation: I-205 Columbia River bridge south channel extension, Portland, Oregon-Vancouver, Washington: Portland, Oregon, CH2M-Hill, $45 \mathrm{p}$.

Swanson, R. D., 1986, A stratigraphic-geochemical study of the Troutdale Formation and Sandy River Mudstone in the Portland Basin and lower Columbia River Gorge [M.S. thesis]: Portland, Oregon, Portland State University, $103 \mathrm{p}$.

Tolan, T. L., 1982, The stratigraphic relationships of the Columbia River Basalt Group in the lower Columbia River Gorge of Oregon and Washington [M.S. thesis]: Portland, Oregon, Portland State University, $151 \mathrm{p}$.

Tolan, T. L., and Beeson, M. H., 1984a, Intracanyon flows of the Columbia River Basalt Group in the lower Columbia River Gorge and their relationship to the Troutdale Formation: Geological Society of America Bulletin, v. 95, no. 4, p. 463-477.

1984b, Exploring the Neogene history of the Columbia River:

Discussion and geologic field trip guide to the Columbia River

Gorge, Part I: Oregon Geology, v. 46, no. 8, p. 87-97.

1984c, Exploring the Neogene history of the Columbia River:

Discussion and geologic field trip guide to the Columbia River Gorge, Part II: Oregon Geology, v. 46, no. 9, p. 103-112.

Treasher, R. C., 1942a, Geologic history of the Portland area: Oregon Department of Geology and Mineral Industries Short Paper 7, 17 p.

1942b, Geologic map of the Portland area: Oregon Department of Geology and Mineral Industries, Portland, Oregon.

Trimble, D. E., 1957, Geology of the Portland quadrangle, OregonWashington: U.S. Geological Survey, Geologic Quadrangle Map GQ104.

1963, Geology of Portland, Oregon, and adjacent areas: U.S. Geological Survey Bulletin 1119, 119 p., 1 pl. 
Waters, A. C., 1973, The Columbia River Gorge: Basalt stratigraphy, ancient lava dams and landslide dams, in Geologic field trips in northern Oregon and southern Washington: Oregon Department of Geology and Minera1 Industries Bulletin 77, p. 133-162.

Williams, I. A., 1916, The Columbia River Gorge: Its geologic history interpreted from the Columbia River Highway: Oregon Bureau of Mines and Geology, Mineral Resources of Oregon, v. 2, no. 3, 130 p., 76 p1s.

Willis, R. F., 1977, Ground water exploratory program: Bureau of Water Works, Portland, Oregon, 284 p., 17 p1s.

1978, Pilot well study: Bureau of Water Works, Portland, Oregon, 150 p. 23 p1s.

Wise, W. S., 1969, Geology and petrology of the Mt. Hood area: A study of High Cascade volcanism: Geological Society of America Bulletin, v. 80 , no. 6 , p. $969-1006$.

1970, Cenozoic volcanism in the Cascade Mountains of southern Washington: Washington Division of Mines and Geology Bulletin 60, $45 \mathrm{p}$. 